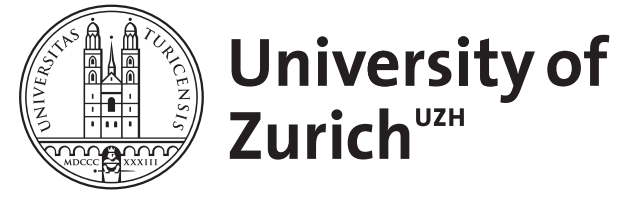

Zurich Open Repository and Archive

University of Zurich

University Library

Strickhofstrasse 39

CH-8057 Zurich

www.zora.uzh.ch

Year: 2005

\title{
Patente am Leben? Ethische, Rechtliche und Politische Aspekte der Biopatentierung
}

Schefczyk, Michael

DOI: https://doi.org/10.1007/s10677-005-9359-6

Posted at the Zurich Open Repository and Archive, University of Zurich ZORA URL: https://doi.org/10.5167/uzh-156184

Journal Article

Published Version

Originally published at:

Schefczyk, Michael (2005). Patente am Leben? Ethische, Rechtliche und Politische Aspekte der Biopatentierung. Ethical Theory and Moral Practice, 8(3):321-323.

DOI: https://doi.org/10.1007/s10677-005-9359-6 
Ethical Theory and Moral Practice 8: 321-323, 2005.

DOI: $10.1007 / \mathrm{S} 10677-005-9359-6$

BOOK REVIEW

Christoph Baumgartner and Dietmar Mieth (ed.), Patente am Leben? Ethische, Rechtliche und Politische Aspekte der Biopatentierung. Mentis Verlag, Paderborn, 2003, 332 pp.,€ 29.80

Who would have anticipated three decades ago that patent law would soon become a hotbed of heated philosophical and political debates? The emergence of the biotechnological industry turned a dry word like 'patent' into an ideological shibboleth. In some quarters of society, whether you are for or against biopatents is no less significant than it once was whether you are for or against the private ownership of the means of production. The question, of course, concerns in both cases a complex matter and calls for a multilayered answer. The anthology 'Patente am Leben?' is an enormously helpful reading for those who are fond of seeing such complicated issues from different professional, theoretical and ideological angles. Since only four of its fifteen contributions are in English, this publication addresses mainly the German-reading public. The first section sets the stage with articles by four representatives of organisations, which play an important part in structuring this field of policy. The piece by Reinhard Hermann, director of the biotechnology department at the European Patent Office, aims at convincing the laymen that biopatents are less problematic than they may imagine. In his concluding remark, he voices the view that the agitation about biopatents typically rests on a serious overestimation of the significance of particular genes or genes in general for human life. At the other end of the ideological spectrum stands the contribution of Christopher Then, expert for issues of genetic engineering and biopatents at Greenpeace. He argues for the view that patents on genes boil down to a systematic abuse of patent law, because they grant a temporary monopoly on the use of a discovery and not - as it should be - on the use of an invention. Unfortunately, at many points the somewhat polemical tone of the piece makes it sound like a less than reliable source of information.

The second part of the collection is devoted to the ethical aspects of biopatenting. Dietmar Mieth approaches the issue from a perspective of social ethics. The main reservation of his well-informed paper concerns the practice of patenting biological material (Stoffpatente). Like Then, Mieth 
avers that this practice is against the spirit of the patent system, which should further technological progress but not commercial privileges. Even more important for his stand is a metaphysical objection against the materialism of modern biology that, according to him, is reflected in the patent system.

The contribution 'Biopatente - eine ethische Analyse' is extracted from an expert report by N. Anwander, A. Bachmann, K.P. Rippe and P. Schaber for the Swiss government. The report rejects what may be called the 'commodification objection against biopatents'. This objection considers patents on biological material to be a violation of the intrinsic value of creatures (Würde der Kreatur), which is protected by the Swiss constitution. The article points out that patents do not violate the intrinsic value of an individual creature, since they refer to types and not to tokens. For instance, it is the idea of how to produce and commercially use the oncomouse that is legally protected; and the legal protection of the commercial use of an idea cannot possibly violate the intrinsic value of a particular specimen. Nevertheless, the report expresses qualms about biopatents. Like other articles in the collection, the authors recommend that biopatents should only be granted for procedures, not products, since genes can be discovered but not invented. Moreover, they see the staking of private property claims by means of biopatents as a blatant violation of the Common Heritage of Mankind.

The third part of the anthology deals with the legal aspects of the matter. The contributions of Geertrui van Overwalles and Christine Godt point out that biopatents tend to have a detrimental effect on the research at universities. Godt's article recommends a strategic approach that copes with the trade-off between the commodification of research and the traditional communism (R. Merton) of the scientific community. In contrast, van Overwalles joins forces with the obviously considerable number of product claim critics.

The fourth part of the book focuses on the range and consequences of product claims. Ingrid Schneider's contribution gives an informative policy analysis of the issue, whereas Henk van Belt and Bernd Nilles investigate the consequences of the Treaty on Trade Related Aspects of Intellectual Property (TRIPS) for global economic opportunities. Both authors arrive at the conclusion that TRIPS in its current form is to the disadvantage of the less developed world.

A documentation of legal texts and a glossary complement the anthology in a helpful way, but do not fully compensate for the absence of an index, which is a serious flaw in an otherwise very valuable book. 
MICHAEL SCHEFCZYK

Universität Zürich

Philosophisches Seminar

Zollikerstrasse 117

CH-8008 Zürich

Switzerland

E-mail: Michael.Schefczyk@access.unizh.ch 